\title{
Challenges and adaptive strategies in pig breeding from the aspect of heat stress and heat tolerance
}

\section{István Nagy , György Kövér ${ }^{2}$, Zsolt Gerencsér ${ }^{1 *}$, Gabriella Szász ${ }^{3}$}

\author{
${ }^{1}$ Kaposvár University, Faculty of Agricultural and Environmental Sciences, H-7400 Kaposvár, Guba S. \\ str. 40; \\ ${ }^{2}$ Kaposvár University, Faculty of Economic Science, H-7400 Kaposvár, Guba S. str. 40; \\ ${ }^{3}$ Vat Balance Kft, H-1145 Budapest, Róna str. 215
}

\begin{abstract}
Authors summarized the results of the last three decades' relevant literature examining the temperature effects on the various growth, reproductive and carcass traits in pigs. The ideal period of temperature measurement and the different methodologies characterizing temperature effects were summarized. The aspects of genotype environment interaction for the measured traits under hot and temperate conditions were also presented. Finally the possibilities of direct genetic selection for heat tolerance and its possible selection criteria traits were also discussed.
\end{abstract}

Keywords: robust pig, heat stress, heat tolerance, genotype environment interaction

\section{INTRODUCTION}

Quantitative genetic methods have been applied by animal breeders for decades in order to improve certain traits. The realisation of this effort is visible through the obtained genetic trends of the selected traits. By determining the genetic parameters (heritability, genetic correlation coefficients) the most suitable methods (e.g. self performance test, progeny test) also become obvious making possible maximising the genetic gain. As pointed out by Merks et al. (2012) the definition of the overall breeding objective or breeding goal is an essential step in any breeding program. The traits included in the breeding goals should be specific, measurable attainable, realistic and timely (Merks et al., 2012). Until recently some of the most frequent selection criteria traits of the pig breeding sector were litter size (Hanenberg et al. 2001.; Krupa and Wolf, 2013; Nagyné-Kiszlinger et al., 2013), average daily gain, lean meat percentage (Ibanez-Escriche et al., 2011; Nagyné-Kiszlinger et al., 2011; GjerlaugEnger et al., 2012) and dressing out percentage (Ciobanu et al., 2011), respectively. Recently robustness of pigs gained importance (Knapp, 2005), as the pig sector is increasingly being effected by hot climate. The consequence of robustness is that pigs can adapt to different stressors without stress (Merks et al., 2012). The different stressors can cause leg weakness, nutritional deficit dur- 
ing lactation, various diseases and lowered reproductive performance (Dourmad et al., 2010; Merks et al., 2012; Hermesch et al., 2015). In pigs ambient temperature one of the most important stressors as they have very limited ability for thermo regulation through perspiration. Therefore extreme temperature results in increased production difficulties and increased animal losses (Black et al., 1993). As noted by Hayes et al. (2013) global warming is likely to lead to hotter climates than in the recent past. Fortunately robustness can be implemented as a breeding objective trait just like production traits, although it requires substantial investment in data and technology (Knapp, 2005). The importance of taking the temperature effects into account when evaluating performance is inevitable. However, the relevant literature is not uniform describing how temperature measurement should be recorded and utilized. Therefore the objective of this review paper was to summarize the relevant literature in order to demonstrate how to take into account the temperature's influence on the pigs' performances and how to quantify the effects of the increased temperature on the pigs' performance. Besides, further objectives of this study were to describe the genetic differences among the various pig lines concerning heat tolerance and to show the potential selection criteria traits that could be utilized in the breeding programs making pigs more robust from the aspect of heat tolerance.

\section{MEASURING THE EFFECT OF HIGH TEMPERATURE ON THE REPRODUC- TIVE, GROWTH AND CARCASS TRAITS OF THE PIGS}

\section{Data source}

In pig breeding the possible effects of high temperature can only be quantified after obtaining reliable temperature measurements. According to the relevant literature no temperature measurements were taken in any pig farm directly but in all studies the necessary temperature data were obtained from the nearest meteorological station. The R package "WeatherData” (Narasimhan, 2014) is worth mentioning as a collective device for such data. The distance between the meteorology stations and the pig farms showed high variability (3 to 209 km) (Bloemhof et al., 2008, 2013; Zumbach et al., 2008a; Auvigne et al., 2010; Lewis and Bunter, 2010, 2011; Iida and Koketsu, 2014; Knecht et al., 2015; Fragomeni et al., 2016; Wegner et al., 2016). Nevertheless, in most cases the nearest wheather station was located within $70 \mathrm{~km}$ from the farms. Besides, Freitas et al. (2006) reported high correlation (0.9) between on farm weather data and weather station data $300 \mathrm{~km}$ away from the farms. It can thus be concluded 
that in the above mentioned studies the precision of the weather data was satisfactory from the aspect of evaluating heat stress and heat tolerance.

\section{Time and method of measurement}

Another issue is that temperature can be measured continuously and the effects of this variable on the various traits has to be determined. From the different strategies the most simple one is to record and utilize the daily maximum temperature at a given day for example at the day of the insemination (Bloemhof et al., 2008), or at the last day of the fattening period (Lewis and Bunter, 2010). However, several authors utilized temperature records for a given period both for reproductive (Bloemhof et al., 2013: 7 and 12 days before and after the succesful insemination) and for carcass traits (Zumbach et al., 2008b: last 10 weeks of the fattening; Fragomeni et al., 2016: last 30-70 days of the fattening). According to Wegner et al. (2016) temperature measurements were taken during several days around insemination and farrowing. Afterwards, these measurements were used separately in order to determine the most influential day. Wegner et al. (2016) found that the greatest negative effect occurred 4 days prior to breeding. Fragomeni et al. (2016) and Zumbach et al. (2008a) used another strategy which made possible to aggregate all temperature measurements of a period into one number. According to Fragomeni et al. (2016) temperature humidity index (THI) was calculated for each day using the formula:

$$
\mathrm{THI}=(1.8 \times \mathrm{t}+32)-[0.55-(0.0055 \times \mathrm{rh})] \times(1.8 \times \mathrm{t}-26),
$$

where $\mathrm{t}=$ the observed maximum temperature in degrees Celsius, $\mathrm{rh}=$ the observed minimum humidity on a 0 to 100 scale.

Then the heat load (HL) was calculated using the formula:

$$
\mathrm{HL}=\operatorname{maximum}\left(0, \mathrm{THI}-\mathrm{THI}_{\mathrm{T}}\right) \text {, }
$$

where $\mathrm{THI}=$ temperature humidity index for a given day, $\mathrm{THI}_{\mathrm{T}}=\mathrm{a}$ threshold THI value (generally from 60 to 77) which can be interpreted as the maximum range of the thermal neutral zone. After HL was determined for every day mean HL within 30-70 day before slaughter was calculated taking into account the cumulative effects of heat stress (Fragomeni et al., 2016). Zumbach et al. (2008a) also calculated heat load but in their case after calculating weekly heat 
load (as the mean THI exceeding threshold) the total heat load was the sum of the heat loads over the last " $n$ " weeks of life.

\section{Evaluation method}

The temperature effect on the various traits can be quantified using either linear regression (Bloemhof et al., 2008; Iida and Koketsu, 2014; Wegner et al., 2016) or plateau-linear regression (Bloemhof et al., 2008, 2013; Zumbach et al., 2008a; Lewis and Bunter, 2010; Fragomeni et al., 2016). In both types of analyses prior to the regression the data has to be corrected for other influential factors such as parity, service sire, herd-year etc. Generally a GLM procedure can be applied (e.g. Bloemhof et al., 2008; Lewis and Bunter, 2010) taking into account all the influential factors calculating the corrected phenotypes of the examined traits. Then the effect of temperature can be determined by regressing the corrected phenotypes on the temperature values. An important point is that pigs are exposed to heat stress when temperature exceeds the upper critical temperature (UCT) of the thermo-neutral zone (Bloemhof et al., 2008). According to Black et al. (1993) the zones of comfort for the lactating sow and for the piglets are between 12 and $22{ }^{\circ} \mathrm{C}$ and between 30 and $37^{\circ} \mathrm{C}$, respectively. According to the plateau-linear model the increasing temperature has no effect on the pigs' performance until the temperature does not exceed the UCT value the. On the contrary, if the temperature is higher than the UCT value then a decrease can be observed which can be quantified by the regression coefficient.

\section{Effects of temperature}

In Table 1 the temperature effect on several performance traits are summarized.

It can be seen that in some studies (Table 1) no UCT value could be determined (Bloemhof et al., 2008; Iida and Koketsu, 2014). This means that certain pig lines were not sensitive for heat stress and they showed no or only limited performance decrease even at high temperatures (Table 1). Based on Bloemhof et al. (2008) the Topigs I-line was originated from purebred Large White sow line. Accodring to the the reports of this study the nucleus farms were operated for more than 15 years in Spain. So probably the well performing families in hot environments were selected. On the other hand some breeds could also show substantial decrease of performances based on the linear regression. Iida and Koketsu (2014) examined the performances of gilts and sows serviced during the hot and humid season between June and September. Based 
on the results the exceeding preservice temperature resulted a larger decrease in the sows compared to gilts. Stress during postservice was less pronounced $\left(-0.014\right.$ piglet $/{ }^{\circ} \mathrm{C}$ and -0.093 piglet $\left./{ }^{\circ} \mathrm{C}\right)$ for the gilts and for the sows, respectively. Wegner et al. (2016) noted that number of piglets born alive was the most sensitive reproductive trait affected by heat stress. Both Wegner et al. (2016) and Iida and Koketsu (2014) emphasized the necessity of improvements in isolation and cooling systems (starting from the preservice periods) in order to sustain the high productivity of gilts and sows limiting the negative consequences of heat stress.

\section{Table 1}

The effect of temperature on the reproductive, growth and carcass traits of the pigs

\begin{tabular}{|c|c|c|c|c|}
\hline Author & Breed/Line & Traits & $\mathrm{UCT}^{\circ} \mathrm{C}$ & Effect \\
\hline \multirow[t]{3}{*}{ Bloemhof et al., 2008} & Topigs & FR & 19.2 & $-1 \% /{ }^{\circ} \mathrm{C}$ \\
\hline & D-line & NBA & 19.6 & -0.05 piglet $/{ }^{\circ} \mathrm{C}$ \\
\hline & & TNB & 19.6 & -0.13 piglet $/{ }^{\circ} \mathrm{C}$ \\
\hline \multirow{3}{*}{ Bloemhof et al., 2008} & Topigs & FR & - & - \\
\hline & I-line & NBA & - & -0.01 piglet $/{ }^{\circ} \mathrm{C}$ \\
\hline & & TNB & - & -0.02 piglet $/{ }^{\circ} \mathrm{C}$ \\
\hline \multirow[t]{3}{*}{ Bloemhof et al., 2013} & Topigs & FR & 20.9 & $-1 \% /{ }^{\circ} \mathrm{C}$ \\
\hline & D-line & TNB & & \\
\hline & & & 20 & -0.05 piglet $/{ }^{\circ} \mathrm{C}$ \\
\hline Zumbach et al., 2008a & Du x (LW x LR) & BWSL & & $\begin{array}{l}-6 \mathrm{~kg} \\
\text { (stress vs. no } \\
\text { stress) }\end{array}$ \\
\hline \multirow[t]{3}{*}{ Lewis and Bunter, 2010} & LR & ADGL & 25.5 & $-0.38 \mathrm{~kg} /{ }^{\circ} \mathrm{C}$ \\
\hline & LW & & 32.5 & $+0.82 \mathrm{~kg} /{ }^{\circ} \mathrm{C}$ \\
\hline & & $\mathrm{BF}$ & 30.6 & $-0.028 \mathrm{~mm} /{ }^{\circ} \mathrm{C}$ \\
\hline Iida and Koketsu, 2014 & - & TNB & - & $\begin{array}{l}-0.05 \text { piglet } /{ }^{\circ} \mathrm{C} \\
-0.14 \text { piglet } /{ }^{\circ} \mathrm{C}\end{array}$ \\
\hline \multirow[t]{2}{*}{ Fragomeni et al., 2016} & $\mathrm{Du}$ & BW & - & $\begin{array}{l}-2 \mathrm{~kg} / 10 \mathrm{HL} \\
+3 \mathrm{~kg} / 12 \mathrm{HL}\end{array}$ \\
\hline & $\mathrm{LR} \times \mathrm{LW}$ & $\begin{array}{l}\text { HCW } \\
\text { LS }\end{array}$ & - & $\begin{array}{c}-7 \mathrm{~kg} / 12 \mathrm{HL} \\
-0.03 \text { piglet } /{ }^{\circ} \mathrm{C}\end{array}$ \\
\hline
\end{tabular}

LR: Landrace; LW: Large White; Du: Duroc; FR: farrowing rate; NBA: number of piglets born alive; TNB: total number of born piglets; BWSL: body weight at slaughter; ADGL: lifetime average daily gain; HCW: hot carcass weight; LS: litter size; UCT: upper critical temperature; HL: heat load

In several studies (Bloemhof et al., 2008, 2013; Lewis and Bunter, 2010; see in Table 1) the deterioration of the pigs' performance became substantial after the temperature exceeded the UCT value. There are various reasons explaining the existence of UCT temperatures but one of the most evident is the origin of 
the used breed or line. Bloemhof et al. (2008) reported that the Topigs D-line was originated from purebred Dutch Yorkshire sow line. In the Netherlands experiencing a heat stress is unlikely. Therefore it is not surprising that the Topigs D line was not performing well during heat stress. From Table 1 it is well recognisable that the UCT values are highly different among the different traits. Related to reproductive traits the UCT values were around $20{ }^{\circ} \mathrm{C}$ while UCT values were much higher for growth traits (Table 1). According to Lewis and Bunter, (2010) the two sow lines differed from each other in heat tolerance. The same tendency was observed for average daily gain and backfat. The positive change in backfat is surprising however, as noted by Gentry et al. (2002) fat levels can increase during times of heat stress as deposition of protein moves from proteins to lipids.

The study of Zumbach et al. (2008a) and Fragomeni et al. (2016) differed from other studies as the effect of temperature was not measured on the original temperature scale but on a heat load scale constructed from temperature humidity index. The value of the threshold THI, the length of the evaluated period and the different examined regions all influenced the results. The body weight before slaughter gave discordant results in the different regions, although the magnitude of the changes was not substantial. Using the coefficient of determination the best data fitting was obtained with a 74 THI threshold and 30 day long evaluating period (until slaughter) (Fragomeni et al., 2016). Not quite in line with the previous study Zumbach et al. (2008a) observed the highest coefficient of determinations when the evaluation monitored the last 10 weeks before slaughter.

\section{GENOTYPE ENVIRONMENT INTERACTION}

Bloemhof et al. (2008) noted that although the Topigs D-line had a higher reproductive performance than the I-line under normal (temperate) conditions, the I-line sows became superior when the temperature raised higher than 25 ${ }^{\circ} \mathrm{C}$. This phenomenon was a clear indication of genotype environment interaction (Bloemhoef et al., 2008). In pig breeding substantial difference between the environment of the performance test and that of the production is often encountered. The reason for these different environments is that during the station test the most important objective is to determine the maximum performance of the animals which needs optimal conditions. On the contrary in the course of farm production the available environment is often substantially worse than optimal, with a variety of challenges (diseases, feeding and man- 
agement related issues and climate). As noted by Zumbach et al. (2008b) nucleus farms had 25\% more space available for animals and operated free of numerous disease challenges compared with their commercial counterparts. Therefore in the nucleus farms accounting for genotype by environment interaction is very important (Mathur, 2018).

The observed differences between the performance tests and production depend on the genes influencing the traits measured in the two environments. When the trait equivalents are conrolled by the same genes then the ranking of the breeding animals obtained in an optimal environment will not change in farm conditions. On the contrary when the genetic architecture in different environments is not the same then the ranking of the breeding animals will be different for the test and farm conditions, respectively (Nagy et al., 2003). Genotype environment interaction can be determined in various ways. If the number of different environments is limited to two then the genotype environment interaction can be considered as the genetic correlation between the same traits measured in the different environments (Falconer, 1952). If the estimated genetic correlation coefficient is high $(>0.8)$ then the ranking of the breeding animals will be independent from the different environmental conditions (Bidanel and Ducos, 1995, 1996). On the contrary the estimated genetic correlation between these trait equivalents is not high $(<0.8)$ then the result suggests that genotype environment interaction affects the measurements and re-ranking would be observed between the different environments. If the genetic correlation between the performance in two environment is lower that 0.4-0.6, then creating separate lines becomes necessary (Mulder and Bijma, 2006).

Studies analysing the genetic environmental interaction from climate aspects could be sorted to two types. In the first type the location was the same and the different seasons were considered as the different environments (Zumbach et al., 2008b; Lewis and Bunter, 2011; Bunz et al., 2019). In the second type the temperate and hot climate was studied at different countries (Loyau et al., 2017; Godinho et al., 2019). The estimated genetic correlations for production, carcass and for the reproductive traits between different environments are presented in Tables 2-3.

The various studies analyzing growth, carcass and reproductive traits gave diverse results (Tables 2-3). Most estimates were high enough $(>0.6)$ and not indicating substantial genotype environment interaction. However Zumbach et al. (2008b) and Loyau et al. (2017) reported quite low genetic correlation $(<0.50)$ between hot and temperate environments for growth and carcass traits. Bunz et al. (2019) observed that when the temperature is high prior and 
post mating in one environment and low prior and post mating in the other environment then the genetic environment interaction is apparent (Table 3). Farrowing rate in these two environments were clearly separate traits which must be included in breeding program independently. It also has to be noted that when Godinho et al. (2019) examined the genetic correlation between purebreds (measured in temperate climate) and crossbreds (measured tropical climate) the observed genetic correlations were much lower for all examined traits (0.22-0.25) compared to the estimates given in Table 2.

\section{Table 2}

Estimated genetic correlations between different environments for the growth and carcass traits

\begin{tabular}{|c|c|c|c|}
\hline Author & Breed/Line & Traits & $\mathrm{rg}_{\mathrm{g}}$ \\
\hline Zumbach et al., 2008a & Du x (LW x LR) & $\mathrm{CW}_{\mathrm{HS}}-\mathrm{CW}_{\mathrm{NHS}}$ & 0.42 \\
\hline \multirow[t]{12}{*}{ Lewis and Bunter, 2011} & LR & $\mathrm{BF}_{\text {SUMMER }}-\mathrm{BF}_{\text {AUTUMN }}$ & 0.93 \\
\hline & LW & $\mathrm{BF}_{\text {SUMMER }}-\mathrm{B} \mathrm{F}_{\text {WINTER }}$ & 0.88 \\
\hline & & BFSUMMER - BFSPRING & 0.91 \\
\hline & & $\mathrm{BF}_{\text {AUTUMN }}-\mathrm{BF}_{\text {WINTER }}$ & 0.96 \\
\hline & & $\mathrm{BF}_{\text {AUTUMN }}-\mathrm{BF}$ SPRING & 0.95 \\
\hline & & BF WINTER - BF SPRING $_{\text {ST }}$ & 0.85 \\
\hline & & ADGsummer - ADG $_{\text {Autum }}$ & 0.90 \\
\hline & & ADGsuMmer - ADGWINTER & 0.89 \\
\hline & & $\mathrm{ADG}_{\text {SUMMER }}-\mathrm{ADG}_{\text {SPRING }}$ & 0.85 \\
\hline & & $\mathrm{ADG}_{\text {AUTUMN }}-\mathrm{ADG}_{\text {WINTER }}$ & 1.04 \\
\hline & & $\mathrm{ADG}_{\text {AUTUMN }}-\mathrm{ADG}_{\text {SPRING }}$ & 0.89 \\
\hline & & ADG GINTER - ADGsPrING & 0.99 \\
\hline \multirow[t]{5}{*}{ Godinho et al., 2019} & Sire line & $\mathrm{ADG}_{\text {TROP }}-\mathrm{ADG}_{\mathrm{TEMP}}$ & 0.64 \\
\hline & & $\mathrm{LD}_{\text {TROP }}-\mathrm{LD}_{\text {TEMP }}$ & 0.97 \\
\hline & & $\mathrm{PD}_{\mathrm{TROP}}-\mathrm{PD}_{\mathrm{TEMP}}$ & 0.73 \\
\hline & & $\mathrm{BF}_{\text {TROP }}-\mathrm{BF}_{\mathrm{TEMP}}$ & 0.98 \\
\hline & & $\mathrm{MD}_{\text {TROP }}-\mathrm{MD}_{\text {TEMP }}$ & 0.75 \\
\hline \multirow[t]{4}{*}{ Loyau et al., 2017} & LW x CR & $\mathrm{ADG}_{\text {TROP }}-\mathrm{ADG}_{\text {TEMP }}$ & 0.60 \\
\hline & & $\mathrm{BF}_{\text {TROP }}-\mathrm{BF}_{\mathrm{TEMP}}$ & 0.31 \\
\hline & & DFI $_{\text {TROP }}-$ DFI $_{\text {TEMP }}$ & 0.29 \\
\hline & & $\mathrm{BW}_{\text {TROP }}-\mathrm{BW}_{\text {TEMP }}$ & 0.63 \\
\hline
\end{tabular}

LR: Landrace; LW: Large White; Du: Duroc; CR: Créole; CWHs: carcass weight during heat stress; ; CW $_{\mathrm{NHS}}$ : carcass weight during non-heat stress; BF: backfat; ADG: average daily gain; LD: lipid deposition; PD: protein deposition; MD: muscle depth; TROP: tropical environment; TEMP: temperate environment; DFI: average daily feed intake; BW: body weight

This result signals that selection of purebred pigs in the nucleus farms has to be based on the joint evaluation of the purebred and crossbred progeny data (Wei and van der Werf, 1994; Nagyné-Kiszlinger et al., 2011, 2013). Concerning the climatic effects, Zumbach et al. (2008b) concluded that selection under temperate conditions could lead to increased sensitivity to heat stress. This 
conclusion was in accordance with the findings of Falconer (1990). Therefore selection in heat-stress-affected areas should also evaluate performance under heat stress conditions to reduce losses due to heat stress (Zumbach et al., 2008b). Godinho et al. (2019) however noted that the current datasets collected by pig breeding programs make it difficult to obtain accurate estimates of genetic correlations between pig performance in temperate and tropical climates.

\section{Table 3}

Estimated genetic correlations between different environments for the reproductive traits

\begin{tabular}{|c|c|c|c|}
\hline Author & Breed/Line & Traits & $r_{g}$ \\
\hline \multirow[t]{18}{*}{ Lewis and Bunter, 2011} & LR & TB SUMMER $_{\text {- TB }}$ AUTUMN & 1.17 \\
\hline & LW & TBSUMMER - TBWINTER & 0.79 \\
\hline & & TBSUMMER - TBSPRING & 0.80 \\
\hline & & TB AUTUMN - TBWINTER & 0.86 \\
\hline & & TB $_{\text {AUTUMN }}$ - TB SPRING & 0.65 \\
\hline & & TBWINTER - TBSPRING & 0.85 \\
\hline & & NBAsummER - NBAAutumn & 0.90 \\
\hline & & NBA $A_{\text {SUMMER }}-$ NBA $_{\text {WINTER }}$ & 0.86 \\
\hline & & NBAsUMmER - NBAsPRING & 0.76 \\
\hline & & $\mathrm{NBA}_{\text {AUTUMN }}-\mathrm{NBA}_{\text {WINTER }}$ & 0.72 \\
\hline & & NBAAUTUMN - NBAsPRING & 0.70 \\
\hline & & NBA ${ }_{\text {WINTER }}-$ NBA $_{\text {SPRING }}$ & 0.89 \\
\hline & & PBW $_{\text {SUMMER }}-$ PBW $_{\text {AUTUMN }}$ & 0.85 \\
\hline & & PBW $_{\text {SUMMER }}-$ PBW $_{\text {WINTER }}$ & 0.93 \\
\hline & & PBW $_{\text {SUMMER }}-$ PBW $_{\text {SPRING }}$ & 0.85 \\
\hline & & PBW $_{\text {AUTUMN }}-$ PBW $_{\text {WINTER }}$ & 1.08 \\
\hline & & $\mathrm{PBW}_{\text {AUTUMN }}-\mathrm{PBW}_{\text {SPRING }}$ & 0.80 \\
\hline & & $\mathrm{PBW}_{\text {WINTER }}-\mathrm{PBW}_{\text {SPRING }}$ & 0.85 \\
\hline \multirow[t]{6}{*}{ Bunz et al., 2019} & Sire line & $\mathrm{FR}_{1}-\mathrm{FR}_{3}$ & 0.82 \\
\hline & & $\mathrm{FR}_{1}-\mathrm{FR}_{4}$ & 0.85 \\
\hline & & $\mathrm{FR}_{1}-\mathrm{FR}_{5}$ & -0.10 \\
\hline & & $\mathrm{FR}_{3}-\mathrm{FR}_{4}$ & 0.98 \\
\hline & & $\mathrm{FR}_{3}-\mathrm{FR}_{5}$ & 0.79 \\
\hline & & $\mathrm{FR}_{4}-\mathrm{FR}_{5}$ & 0.89 \\
\hline
\end{tabular}

LR: Landrace; LW: Large White; Du: Duroc; TB: total piglet born; NBA: number of piglets born alive; PBW: piglet weight at birth; FR: farrowing rate; 1: high temperature prior and post mating; 3: high temperature prior and medium temperature post mating; 4 : meadium temperature prior and post mating; 5: low temperature prior and post mating

\section{POSSIBILITIES FOR DIRECT SELECTION ON HEAT RESISTANCE}

The definition of a heat tolerant animal is not obvious. As mentioned by Carabano et al. (2019) from the animal breeding aspect it means maintaining the productive and reproductive levels under hot conditions. Carabano et al. 
(2019) suggested several criteria traits in order to identify heat tolerant animals such as body temperature, respiration rate or heart rate. Body temperature and rectal temperature of pigs and production of lactating sows were analyzed by Gourdine et al. (2017). Although the rectal and cutaneous temperature showed moderate heritabilities (0.34-0.35), the estimated genetic correlation coefficients were not significantly different from zero between these traits and the production traits (average daily feed intake, litter body weight gain, change of the sow's body weight during lactation). Bloemhof et al. (2012) defined heat load index as the deviation of the maximum temperature on the day of insemination from $19.3^{\circ} \mathrm{C}$, when maximum temperature at insemination day was higher than $19.3^{\circ} \mathrm{C}$. Otherwise the heat load index was set to 0 . Heat load index was then defined as relative change in farrowing rate per unit change in heat load index. It was estimated through the slope of random regression line considering farrowing rate as the dependent variable and the heat load as the independent variable. For Topigs Dutch line and International lines and for crosspbred pigs at $29.3^{\circ} \mathrm{C}$ (i.e. heat load index of 10 ) the heritability estimates for heat tolerance were low (0.04-0.05). Nevertheless, Bloemhof et al. (2012) concluded that genetic variation for heat tolerance existed and there were possibilities for genetic improvement. It is important that selection candidates have tested relatives both in temperate and in hot conditions (Bloemhof et al., 2012).

\section{CONCLUSIONS}

In the light of the recent climate change, developing heat tolerant animals is gaining importance. Based on the literature genetic improvement for heat tolerance is possible using different strategies. One of the alternatives is using the concept of genotype environment interaction collecting measurements from the progenies of the breeding candidates kept under hot and temperate conditions. Thus selection will improve traits which are generally used in the pig breeding programs. The other possibility is to define traits directly related to heat tolerance. Pig breeding programmes can be extended with these traits increasing heat tolerance.

\section{ACKNOWLEDGEMENTS}

The research was supported by the EFOP-3.6.3-VEKOP-16-2017-00008 project. 


\section{REFERENCES}

Auvigne V., Leneveu P., Jehannin C. Peltoniemi O. Sallé E. (2010). Seasonal infertility in sows: A five year field study to analyze the relative roles of heat stress and photoperiod. Theriogenology, 74(1), 6066. DOI: 10.1016/j.theriogenology.2009.12.019

Bidanel J.P., Ducos A. (1995). Corrélations Génétiques entre les caractéres mesurés dans les stations publiques et en élevage dans les races porcines Large White et Landrace Francais. Journées Rech. Porcine en France, 27, 143-148.

Bidanel J.P., Ducos A. (1996). Genetic correlations between test station and on-farm performance traits in Large White and French Landrace pig breeds. Livest. Prod. Sci., 45(1), 55-62. DOI: 10.1016/03016226(95)00079-8

Black J.L., Mullan B.P., Lorschy M.L., Giles L.R. (1993). Lactation in the sow during heat stress. Livest. Prod. Sci., 35(1-2), 153-170. DOI: 10.1016/0301-6226(93)90188-n

Bloemhof S., van der Waaij E.H., Merks J.W.M., Knol E.F. (2008). Sow line differences in heat stress tolerance expressed in reproductive performance traits. J. Anim. Sci., 86(12), 3330-3337. DOI: $\underline{10.2527 / j a s .2008-0862}$

Bloemhof S., Kause A., Knol, E.F., Van Arendonk J.A.M., Misztal, I. (2012). Heat stress effects on farrowing rate in sows: Genetic parameters estimation using within-line and crossbred models. J. Anim. Sci., 90(7), 2109-2119. DOI: 10.2527/jas.2011-4650

Bloemhof S., Mathur P.K. Knol E.F. van der Waaij E.H. (2013). Effect of daily environmental temperature on farrowing rate and total born in dam line sows. J. Ami. Sci., 91(6), 2667-2679. DOI: $\underline{10.2527 / j a s .2012-5902}$

Bunz A.M.G., Bunter K.L., Morrison R., Luxford B.G., Hermesch S. (2019). Genotype by temperature grouping interaction for farrowing rate at first insemination. Proc. Assoc. Advmt. Anim. Breed. Genet., 23, 155-158.

Carabano M.J., Ramón M., Menéndez-Buxadera A., Molina A. Díaz C. (2019). Selecting for heat tolerance. Anim. Front., 9(1), 62-68. DOI: 10.1093/af/vfy033

Ciobanu D.C., Lonergan S.M., Huff-Lonergan E. (2011). Genetics of meat and carcass traits. In: Rothschild, M.F, Ruvinsky, A. (Ed.): The Genetics of the Pig, 2nd Edition. CABI International, Wallingford, UK. 355-389.

Dourmad J.Y., Canario L., Gilbert H., Merlot E., Quesnel H., Prunier A. (2010). Évolution des performances et de la robustesse des animaux en élevage porcin. INRAE Prod. Anim., 23(1), 53-64. DOI: 10.20870/productions-animales.2010.23.1.3287

Falconer D.S. (1952). The problem of environment and selection. The American Naturalist, 86, 293-298.

Falconer D.S. (1990). Selection in different environments: Effects on environmental sensitivity (reaction norm) and on mean performance. Genet. Res., 56(1), 57-70. DOI: $\underline{10.1017 / s 0016672300028883}$

Freitas M.S. Misztal I., Bohmanova J. West J. (2006). Utility of on- and off-farm wheather records for studies in genetics of heat tolerance. Livest Sci., 105(1-3), 223-228. DOI: $\underline{10.1016 / j . l i v s c i .2006 .06 .011}$

Fragomeni B.O., Lourenco D.A.L., Tsuruta S., Andonow S., Gray K., Huang Y., Misztal I. (2016). Modelling response to heat stress in pigs from nucleus and commercial farm sin different locations in the United States. J. Anim. Sci., 94(11), 4789-4798. DOI: 10.2527/jas.2016-0536

Gentry J.G., McGlone J.J., Miller M.F. Blanton J. R. (2002). Diverse birth and rearing environment effects on pig growth and meat quality. J. Anim Sci. 80(7), 1707-1715. DOI: $\underline{10.2527 / 2002.8071707 x}$

Gjerlaug-Enger E., Kongsro J., Odegard J., Aass L., Vangen O. (2012). Genetic parameters between slaughter pig efficiency andgrowth rate of different body tissues estimated by computedtomography in live boars of Landrace and Duroc. Animal, 6(1), 9-18. DOI: $\underline{10.1017 / s 1751731111001455}$ 
Godinho R.M., Bergsma R., Silva F.F., Sevillano C.A., Knol E.F., Komen H., Guimares E.F., Lopes M.S., Bastiaansen J.W.M. (2019). Genetics correlations between growth performance and carcass traits of purebred and crossbred pigs raised in tropical and temperate climates. J. Anim. Sci., 97(9), 36483657. DOI: $10.1093 /$ jas/skz229

Gourdine J.L., Mandonnet N., Giorgi M., Renaudeau D. (2017). Genetic parameters for thermoregulation and production traits in lactating sows in tropical climate. Animal, 11(3), 365-374. DOI: $\underline{10.1017 / s 175173111600135 x}$

Hanenberg E.H.T., Knol E.F., Merks J.W.W. (2001). Estimates of genetic parameters for reproduction traits at different parities in Dutch Landrace pigs. Livest. Prod. Sci., 69(2), 179-186. DOI: $10.1016 / \mathrm{s} 0301-6226(00) 00258-x$

Hayes B.J., Lewin H.A., Goddard M.E. (2013). The future of livestock breeding: genomic selection for efficiency, reduced emissions intensity, and adaptation. Trends Genet., 29(4), 206-214. DOI: 10.1016/j.tig.2012.11.009

Hermesch S., Li L., Doeschl-Wilson, Gilbert H. (2015). Selection for productivity and robustness traits in pigs. Anim. Prod. Sci., 55(12), 1437-1447. DOI: 10.1071/an15275

Ibanez-Escriche N., Reixach J., Lleonart N., Noguera J.L. (2011). Genetic evaluation combining purebred and crossbred data in a pig breeding scheme. J. Anim. Sci., 89(12), 3881-3889. DOI: $\underline{10.2527 / j a s .2011-3959}$

Iida R., Koketsu Y. (2014). Interactions between pre- or postservice climatic factors, parity, and weaning-to first mating interval for total number of pigs born of female pigs serviced during hot and humid or cold seasons. J. Anim. Sci., 92(9), 4180-4188. DOI: 10.2527/jas.2014-7636

Lewis C.R.G., Bunter K.L. (2010). Heat stress: the effects of temperature on production and reproduction traits. AGBU Pig Genetics Workshop, 87-95.

Lewis C.R.G., Bunter K.L. (2011). Effect of seasonality and ambient temperature on genetic parameters for production and reproductive traits in pigs. Anim. Prod. Sci., 51(7), 615-626. DOI: $\underline{10.1071 / a n 10265}$

Loyau T., Rose R., Gilbert H., Renaudau D., Giorgi M., Billon Y., Riquet J., Gourdine J.L. (2017). Climt temperé vs tropical: étude des paramétres génétiques, des caractéres de production et d'adaptation á la chaleur chez le porc en crosissance. Jornées Rechereche Porcine. 49, 19-24.

Knapp P.W. (2005). Breeding robust pigs. Aust. J. Exp. Agr., 45(8), 763-773. DOI: 10.1071/ea05041

Knecht D., Środoń S., Duziński K. (2015). The impact of season, parity and breed on selected reproductive performance parameters of sows. Arch. Anim. Breed., 58(1), 49-56. DOI: 10.5194/aab-58-49$\underline{2015}$

Krupa E., Wolf J. (2013). Simultaneous estimation of genetic parameters for production and litter size traits in Czech Large White and Czech Landrace pigs. Checz J. Anim. Sci., 58(9), 429-436. DOI: 10.17221/6943-cjas

Mathur P. K. (2018). Genotype-environment interactions in pig breeding. In: Proc. 11th WCGALP, Auckland, New Zealand. 668.

Merks J.W.M., Mathur P.K., Knol E.F. (2012). New phenotypes for new breeding goals in pigs. Animal, 6(4), 535-543. DOI: $10.1017 / s 1751731111002266$

Mulder H.A. Bijma P. (2006). Benefits of cooperation between breeding programs in the presence of genotype by environment interaction. J. Dairy Sci., 89(5), 1727-1739. DOI: 10.3168/jds.s0022$\underline{0302(06) 72241-x}$

Nagy I., Csató L., Farkas János, Radnóczi L. (2003). Genotípus x környezet kölcsönhatás becslése hazai sertésfajtáink teljesítményvizsgálati eredményei alapján. Állattenyésztés és Takarmányozás, 52, 297-305. 
Nagyné-Kiszlinger H., Farkas J., Kövér Gy., Onika-Szvath Sz., Nagy I. (2011). Genetic Parameters of Growth Traits from a Joint Evaluation of Purebred and Crossbred Pigs. ACS., 76, 223-226.

Nagyné-Kiszlinger H., Farkas J., Kövér Gy., Nagy I. (2013). Selection for reproduction traits in Hungarian pig breeding, in a two-way cross. Anim. Sci. Pap. Rep., 31, 315-322.

Narasimhan R. (2014). weatherData: Get weather data from the web. R package version 0.4.1. Link

Wegner K., Lambertz C., Das G., Reiner G., Gauly M. (2016). Effects of temperature and temperaturehumidity index on the reproductive performance of sows during summer months under a temperature climate. Anim. Sci. J. 87(11), 1334-1339. DOI: 10.1111/asj.12569

Wei M., van der Werf J.H.J. (1994). Maximizing genetic response in crossbreds using both purebred and crossbred information. Anim. Prod., 59(3), 401-413. DOI: 10.1017/s0003356100007923

Zumbach B., Misztal I., Tsuruta S., Sanchez J.P., Azain M., Herring W., Holl J., Long T., Culbertsonn M. (2008a). Genetic components of heat stress in finishing pigs: Development of a heat load function. J. Anim. Sci., 86(9), 2082-2088. DOI: 10.2527/jas.2007-0523

Zumbach B., Misztal I., Tsuruta S., Sanchez J.P., Azain M., Herring W., Holl J., Long T., Culbertsonn M. (2008b). Genetic components of heat stress in finishing pigs: Parameter estimation. J. Anim. Sci., 86, 2076-2081. DOI: 10.2527/jas.2007-0282 